\title{
Cyanobacterial occurrence and detection of microcystins and saxitoxins in reservoirs of the Brazilian semi-arid
}

\author{
Ocorrência de cianobactérias e detecção de microcistinas e saxitoxinas em \\ reservatórios do semiárido brasileiro
}

\author{
Jessica Roberts Fonseca ${ }^{1}$, Pryscila Cynara Soares Vieira ${ }^{1}$, \\ Paula Kujbida ${ }^{2}$ and Ivaneide Alves Soares da Costa ${ }^{3}$
}

${ }^{1}$ Laboratório de Microbiologia Aquática - LAMAq, Programa de Pós-graduação em Desenvolvimento e Meio Ambiente, Departamento de Microbiologia e Parasitologia, Centro de Biociências, Universidade Federal do Rio Grande do Norte - UFRN, Campus Universitario, BR 101,

Lagoa Nova, CEP 59072-970, Natal, RN, Brazil

e-mail: jrf1986@gmail.com; pcynara@yahoo.com.br
${ }^{2}$ Department of Clinical and Toxicological Analysis, Health Sciences Center, Federal University of Rio Grande do Norte - UFRN, Rua General Gustavo Cordeiro de Farias, s/n,
CEP 59012-570, Natal, RN, Brazil
e-mail:paulask@ufrnet.br

\begin{abstract}
${ }^{3}$ Laboratório de Microbiologia Aquática - LAMAq, Departamento de Microbiologia e Parasitologia, Centro de Biociencias, Universidade Federal do Rio Grande do Norte - UFRN, Campus Universitario, BR 101, Lagoa Nova, CEP 59072-970, Natal, RN, Brazil e-mail: iasoares@cb.ufrn.br
\end{abstract}

\begin{abstract}
Aim: The rapid spread of cyanobacteria in water sources and reservoirs has caused serious environmental damage and public health problems, and consists in a problem that challenges the institutions responsible for providing water to the population. In this study, the quantification of microcystin, saxitoxins and cyanobacteria levels was performed over 3 years in the semi-arid reservoirs of Rio Grande do Norte (Brazil). In addition, we analyzed the seasonal distribution of cyanotoxins and the percentage of cyanobacteria and cyanotoxins which were above the limit established by Brazilian law. Methods: The study was conducted between 2009 and 2011 in four dams with six sites: Armando Ribeiro Gonçalves (ARG) in Itajá, San Rafael (SR) and Jucurutu; Passagem das Traíras (PT); Itans and Gargalheiras (GARG). Cyanobacteria presence were quantified and identified and the presence of microcystins (MCYs) and saxitoxins (STXs) was investigated by ELISA. Results: The densities of cyanobacteria were found to be above the permitted in $76 \%$ of cases. The ELISA results showed that of the 128 samples analyzed, $27 \%$ were above the maximum allowed by the Brazilian Ministry of Health Order 2914/2011. A seasonal pattern for the presence of MCYs was found (0.00227 to $\left.24.1954 \mu \mathrm{g} . \mathrm{L}^{-1}\right)$, with the highest values in the rainy season. There was no clear seasonal pattern for STXs ( 0.003 to $\left.0.766 \mu \mathrm{g} . \mathrm{L}^{-1}\right)$. Conclusions: This study showed the importance of establishing a water quality monitoring for human consumption and its potability standards since the concentration of MCYs in some samples was above the maximum limit allowed by Brazilian law, thus posing a risk to public health since the conventional water treatment is not able to eliminate these potent hepatotoxins.
\end{abstract}

Keywords: microcystin, saxitoxin; ELISA; cyanobacteria; semi-arid reservoirs.

Resumo: Objetivo: A proliferação acelerada de cianobactérias em mananciais e reservatórios tem causado sérios danos ecológicos e à saúde pública, e é um problema que desafia as instituiçóes responsáveis pelo fornecimento de água para a população. Nesse trabalho, foi realizada a quantificação dos níveis de microcistinas, saxitoxinas e cianobactérias ao longo de 3 anos em reservatórios do semiárido do Rio Grande do Norte (Brasil). Além disso, foi avaliada a distribuição sazonal das cianotoxinas e a porcentagem de cianobactérias e cianotoxinas que estavam acima do valor permitido de acordo com a legislaçáo brasileira. Métodos: O estudo foi realizado entre os anos 2009 e 2011 em quatro açudes com seis pontos amostrais: Armando Ribeiro Gonçalves (ARG) em Itajá, São Rafael (SR) e Jucurutu; Passagem das Traíras (PT); Itans e Gargalheiras (GARG). As 
cianobactérias presentes foram quantificadas e identificadas e a presença de microcistinas (MCs) e saxitoxinas (STXs) foi investigada por ELISA. Resultados: As densidades de cianobactérias revelaram-se acima do permitido em $76 \%$ dos casos. Já os resultados de ELISA mostraram que das 128 amostras analisadas, 27\% estavam acima do máximo permitido pela Portaria do Ministério da Saúde 2914/2011. Foi encontrado um padráo sazonal para a presença de MCYs $\left(0.00227\right.$ a $\left.24.1954 \mu \mathrm{g} . \mathrm{L}^{-1}\right)$, com os maiores valores encontrados no período chuvoso. Não foi encontrado um padrão sazonal para STXs (0.003 $\mu \mathrm{g} . \mathrm{L}^{-1}$ a $\left.0.766 \mu \mathrm{g} \cdot \mathrm{L}^{-1}\right)$. Conclusóes: Esse trabalho mostrou a importância de se estabelecer a vigilância da qualidade da água para consumo humano e seu padrão de potabilidade já que a concentração de MCYs em algumas amostras estava acima do limite máximo admissível pela legislação brasileira, representando assim um risco à saúde pública já que o tratamento convencional da água não é capaz de eliminar essas potentes hepatotoxinas.

Palavras-chave: microcistina; saxitoxina; ELISA; cianobactéria; açudes do semiárido

\section{Introduction}

In order to minimize the impact of long periods without rainfall, water reservoirs were built in the semi-arid region of northeastern Brazil to capture water from rainy days and make it available in periods of drought. Besides being used for domestic water supply, the reservoirs can be used for fishing, aquiculture and entertainment (Eskinazi-Sant'Anna et al., 2006; Costa et al., 2006a). These reservoirs have typical characteristics of watersheds of semiarid regions, such as high temperatures and high turbidity throughout the year, associated with the constant state of eutrophication by nutrient input, render these environments naturally vulnerable to cyanobacteria (EskinaziSant'Anna et al., 2006, Costa et al., 2009, Sousa et al., 2008; Vasconcelos et al., 2011; Huszar, 2000; Silva et al., 2011; Bouvy et al., 1999; Molica et al., 2005; Panosso et al., 2007).

Eutrophication is a growing phenomenon in the world (Smith \& Schindler, 2009), as well as the following events of cyanobacteria bloom in many countries and in Brazil (Chorus \& Bartram, 1999; Codd et al., 2005; Carmichael 2001; Bouvy et al., 2000; Molica et al., 2005; Huszar et al., 2000).

Such blooms in water supply reservoirs can cause serious problems to public health and the environment (Codd et al., 2005; BittencourtOliveira \& Molica, 2003; Van Apeldoorn et al., 2007). These events alter the taste and odor of the water and the ecological balance of the aquatic ecosystem. In addition, some cyanobacteria can also produce toxins - the cyanotoxins - and thus generate the so-called toxic blooms issue (Skulberg, 2000; Sinclair et al., 2008), as microcystins (MCYs) and saxitoxins (STXs) which have potent hepatotoxicity and neurotoxicity, respectively, plus the MCs'potential to promote tumors (Van
Apeldoorn et al., 2007; Drobac et al., 2013). As some toxins produced by cyanobacteria are not easily removed by conventional water treatment processes (Dietrich \& Hoeger, 2005), in many countries there are a monitoring mandatory of cyanobacteria and cyanotoxins in drinking water, including in Brazil through the Order No 2914/2011 of the Ministry of Health (MH) (Brasil, 2011).

Exposure to cianotoxins can occur orally (directly) by water and food supplements ingestion. Another form of exposure can occur indirectly through the consumption of foods such as fish, crustaceans, molluscs and plants (Galvão et al., 2009; Papadimitriou et al., 2012; Chen \& Xie, 2005, 2007; Dittmann \& Wiegand, 2006), in which cyanotoxins can bioaccumulate (Gutiérrez-Praena et al., 2013). Furthermore, water contamination via recreational activities, dermal exposure and inhalation may occur (Calijuri et al., 2006). The possibility of poisoning by the use of contaminated water through dialysis can also occur (Jochimsen et al., 1998; Azevedo et al., 2002).

In Rio Grande do Norte (RN) state, cyanobacteria are common in reservoirs used for public supply, but few studies report the presence of STXs and MCYs (Costa et al., 2006b, 2009), indicating the necessity for a systematic monitoring of the concentrations of these cyanotoxins. Thus, the purpose of this study was to determine the potential toxicity of cyanobacterial blooms in four reservoirs in the semi-arid of $\mathrm{RN}$ for a continuous period between 2009 and 2011. Besides this, we investigated seasonal (rainy and dry periods) differences of the distribution of microcystins and saxitoxins as well as the levels of cyanobacteria, and checked whether they were above the limit established by Brazilian law. 


\section{Method}

\subsection{Study site}

The study was conducted between 2009 and 2011 in four eutrophic reservoirs (Figure 1) in the semi-arid region of Rio Grande do Norte, involving six sampling points, three in Armando Ribeiro Gonçalves reservoir (ARG): Itajá (538' $1^{\prime}$ 'South and $36^{\circ} 50^{\prime} 59^{\prime \prime}$ West), São Rafael (SR) (5 47' 27'" South and $36^{\circ} 52^{\prime} 43^{\prime \prime}$ West) and Jucurutu (6 $6^{\circ} 3^{\prime} 3^{\prime \prime}$ and South $37^{\circ} 1^{\prime} 15^{\prime \prime}$ West), and the other three points in the following reservoirs: Passagem das Traíras (PT) (6 $6^{\circ} 27^{\prime} 16^{\prime \prime}$ South and $36^{\circ} 52^{\prime}$ 29" West); Itans ( $6^{\circ} 27^{\prime} 35^{\prime \prime}$ South and $37^{\circ} 5^{\prime}$ '56" West) and Garagalheiras (GARG) (6 $6^{\circ} 27^{\prime} 36^{\prime \prime}$ South and $36^{\circ} 38^{\prime} 28^{\prime \prime}$ West). These reservoirs have volumetric capacity above $5,000 \mathrm{~m}^{3}$ of water, high residence time with intended use for human consumption, fishing, recreation and aquaculture. The region is characterized by high temperatures, long periods of drought and short periods of rain, which are concentrated between February and May, with average annual precipitation of $688.8 \mathrm{~mm}$. Table 1 shows the main characteristics of each reservoir.

\subsection{Sampling}

Monthly water samples were taken at each point. Water samples were collected throughout the water column involving six depths, three of which were in the aphotic zone and the other three in the photic zone. For a single sample of each point, all the six samples were integrated. With the aid of a Van Dorn bottle, integrated aliquots of the water samples were collected for microcystin (MCYs) and saxitoxins (STXs) analysis and phytoplankton count $(200 \mathrm{~mL})$. The latter was fixed with $1 \%$ acetic Lugol. Water samples for MCs and STXs analysis were frozen until data processing.

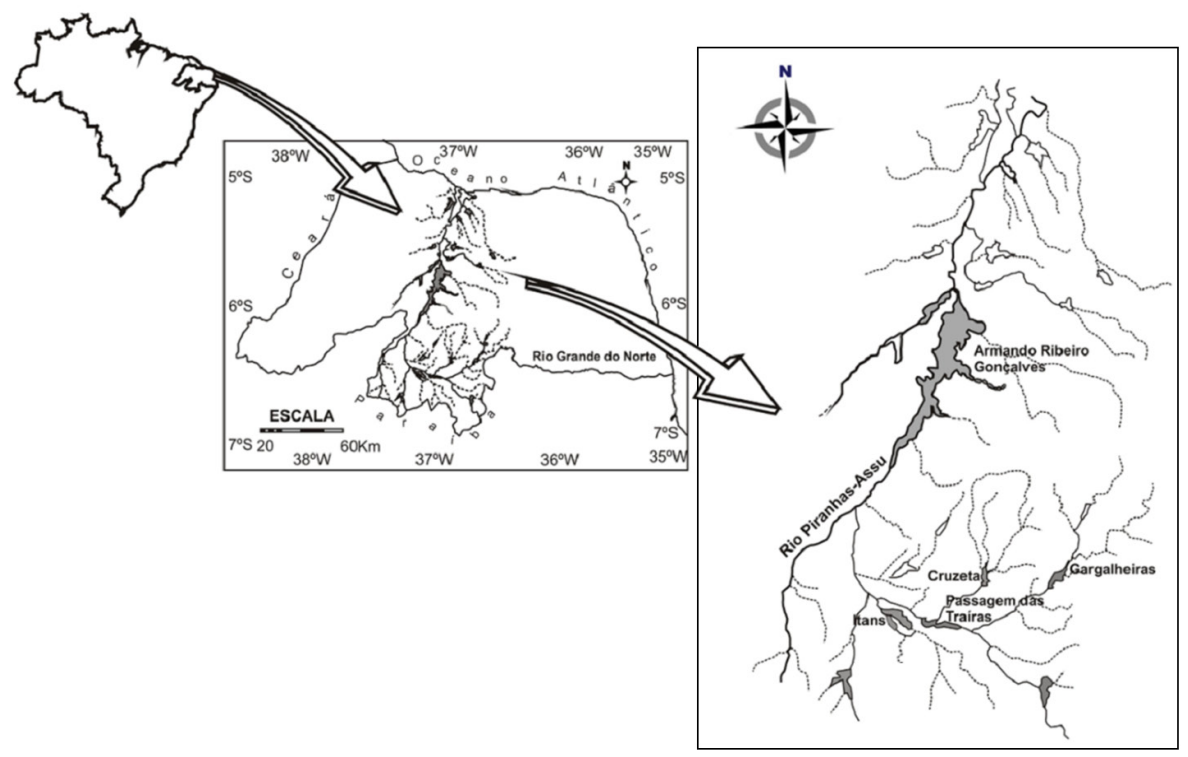

Figure 1. Location of the studied reservoirs (adapted from Costa et al., 2009).

Table 1. Hydrological and morphometric characteristics of the reservoirs.

\begin{tabular}{lcccc}
\hline \multicolumn{1}{c}{ RESERVOIR } & ARG & PT & ITANS & GARG \\
\hline Maximum volume $\left(\times 10^{6} \mathrm{~m}^{3}\right)$ & 2.400 .0 & 48.8 & 81.7 & 44.4 \\
AAV 2009-2011 $\left(\times 10^{6} \mathrm{~m}^{3}\right)$ & 2.055 .0 & 39.2 & 61.3 & 32.5 \\
Zmax (m) & 40 & 25 & 23 & 29 \\
Zm mean (m) & 12.2 & 3.9 & 5.1 & 4.4 \\
RT (m 3 /anos) & 3.65 & 0.26 & 2.46 & 6.22 \\
VMA 2009 (\%) & 95 & 94.0 & 88.2 & 82.1 \\
VMA 2010 (\%) & 77.4 & 31.6 & 63.1 & 52.5 \\
VMA 2011 (\%) & 91.2 & 40.1 & 75.2 & 66.1 \\
\hline
\end{tabular}

ARG: Armando Ribeiro Gonçalves; PT: Passagem das Traíras; GARG: Garagalheiras. Zmax: maximum depth, Zm: average depth. RT: mean residence time; AAV: Annual Average Volume. Source: DNOCS (2014), SEMARH (2010) and Costa et al. (2009). 
Water samples were obtained from a plankton net $(20 \mu \mathrm{m})$ in vertical drags for identifying phytoplankton using living material $(200 \mathrm{~mL})$ and fixed with $4 \%$ formaldehyde $(200 \mathrm{~mL})$.

In each sampling point conductivity, turbidity, temperature, $\mathrm{pH}$ and dissolved oxygen parameters were measured using a multiparameter probe. To estimate the water transparency the depth extinction of the Secchi disk was used. The photic zone was obtained by calculating 2.7 times the estimated water transparency with the Secchi disk (Cole, 1975).

\subsection{Identification and quantification of cyanobacteria}

The identification of cyanobacterial populations and other groups of phytoplankton was performed by microscopy, which was made to the level of species, whenever it was possible, by analysing morphological and morphometric characteristics of the vegetative and reproductive stages. The classification system adopted was Komárek \& Anagnostidis (1998) for the Chroococcales gender, Komárek \& Anagnostidis (2005) for the Oscillatoriales and Komárek \& Anagnostidis (1989) for Nostocales and specialized works for other phytoplankton. The population density was estimated (cel. $\mathrm{mL}^{-1}$ ) by the method of Utermöhl (1958) using the inverted microscope and quantification was done in random fields (Uhelinger, 1964), reaching 100 individuals of the most frequent species, with the error less than 20\% at a confidence interval of $95 \%$ (Lund et al., 1958). In case of bloom, 400 individuals of the dominant species were quantified, resulting in an accepted error of 10\% (Chorus \& Bartram, 1999).

\subsection{Microcystins and saxitoxins analysis}

Water samples were frozen and defrosted three times, filtered with glass fiber filters (Whatman GF/C) and sonicated to lyse the cells, ensuring that the total amount of cianotoxins were analysed: both in the water or in the cytoplasm of the cells. After this process, the samples were analyzed by assay technique of enzyme-linked immunosorbent assay (ELISA) using kits (plate type) Commercial ELISA Beacon mark according to the manufacturer's instructions.

\subsection{Statistical analyses}

Statistical analyses were performed using SPSS Software. Data are expressed as mean values + standard error of mean (SEM). Significant differences between groups (Rainy season X Dry season) were defined as a $p$ value less than 0.05 , and they were determined by $t$-test. In order to identify potential relationships between both physico-chemical variables and microcystins, and physico-chemical variables and saxitoxins, we performed Pearson correlation test with $p$ value less than 0.05 .

\section{Results}

\subsection{Abiotic variables}

The investigated reservoirs showed low transparency ranging between $0.2 \mathrm{~m}$ and $3.5 \mathrm{~m}$; elevated temperatures between $25.2{ }^{\circ} \mathrm{C}$ and 33.5 ${ }^{\circ} \mathrm{C}$ and $\mathrm{pH}$ between neutral and alkaline usually ranging between 6.5 and 10 (Table 2). The volume of the reservoirs (Table 2 and Figure 2) varied over the three years and ranged between $42 \%$ and $100 \%$ of their total capacity, registering lower volumes in 2010 .

A positive correlation was found between the level of microcystins and temperature $(\mathrm{r}=0.325$, $p<0.05$ ) (Figure 3). No statistical correlation was found between microcystins levels and the other physico-chemical variables $(p>0.05)$ and between saxitoxins levels and physico-chemical variables $(p>0.05)$.

Table 2. Limnological variables in reservoirs studied between 2009 and 2011 (Mean, minimum and maximum).

\begin{tabular}{lcccccc}
\hline & ITAJÁ & SR & JUCURUTU & ITANS & PT & GARG \\
\hline $\begin{array}{l}\text { Transparency } \\
(\mathrm{m})\end{array}$ & $1.0(0.5-2.0)$ & $0.8(0.6-1.5)$ & $0.5(0.2-0.9)$ & $1.1(0.5-3.5)$ & $0.7(0.3-1.3)$ & $0.9(0.3-1.3)$ \\
Depth $(\mathrm{m})$ & $25(18-28)$ & $19(12-24)$ & $1.0(0.2-3)$ & $3.6(0.7-8)$ & $1.6(0.5-6)$ & $2.4(0.6-12)$ \\
$\mathrm{pH}$ & $8.4(6.8-9.6)$ & $8.3(6.5-9.4)$ & $7.8(6.6-8.9)$ & $8.7(7.8-9.2)$ & $8.7(7.4-9.5)$ & $8.8(7.4-10)$ \\
Conductivity & 12.4 & 12.8 & 17.5 & 26.3 & 28.6 & 28.5 \\
$\left.(\mathrm{~S} \mathrm{~cm})^{-1}\right)$ & $(9-15.8)$ & $(9-17)$ & $(10-31.3)$ & $(17.7-35.7)$ & $(0.5-47.9)$ & $(19.3-37.3)$ \\
Turbidity & 95.8 & 256.3 & 257.6 & 249.7 & 243.6 & 242.9 \\
$(\mathrm{NTU})$ & $(9.6-720)$ & $(15.5-790)$ & $(55-973)$ & $(8.3-990)$ & $(8.7-816.7)$ & $(11-843.3)$ \\
Temperature & 29 & 29 & 30.3 & 29.4 & 28.6 & 27.9 \\
$\left({ }^{\circ} \mathrm{C}\right)$ & $(27.2-32.2)$ & $(27.1-31.9)$ & $(26.4-33.5)$ & $(26.5-32.1)$ & $(26.1-30.9)$ & $(25.2-32.7)$ \\
\hline
\end{tabular}

SR: São Rafael; PT: Passagem das Traíras and GARG: Garagalheiras. 


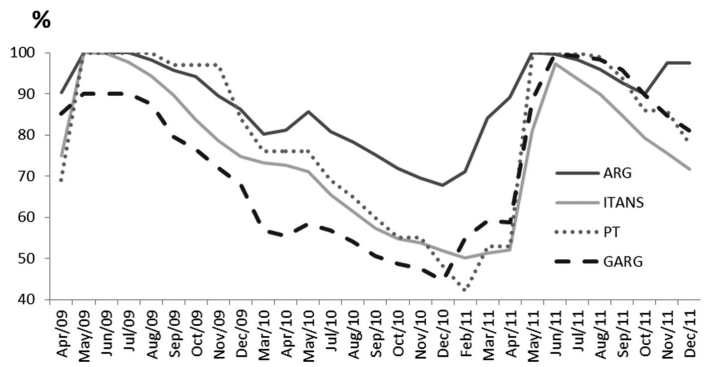

Figure 2. Annual Average Volume (AAV) (\%) between the years 2009 and 2011. ARG: Armando Ribeiro Gonçalves; PT: Passagem das Traíras and GARG: Gargalheiras.

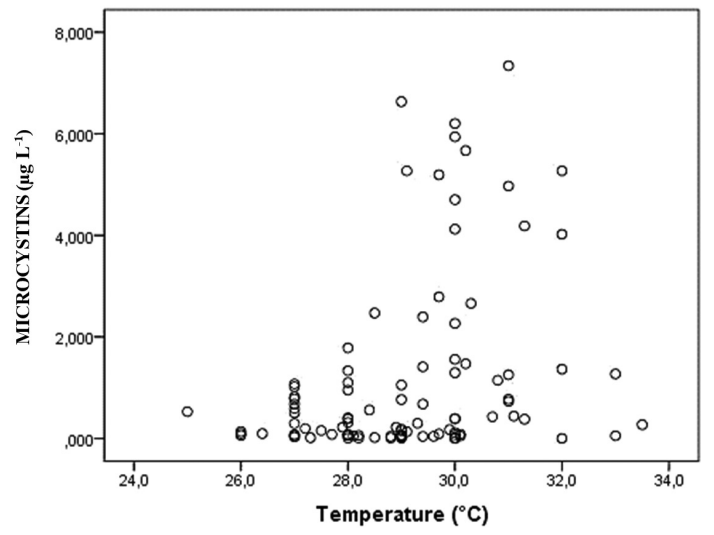

Figure 3. Positive correlation between the level of microcystins and temperature.

\subsection{Microcystins and saxitoxins detection}

Saxitoxins and microcystins were detected in all samples of the four studied reservoirs (Figures 4 and 5), and microcystin was the most frequent with concentrations above those permitted for human consumption, according to Order No 2914/2011 of the Brazilian Ministry of Health (MH) (Brasil, 2011) which regulates the water potability standards. In 2010 the highest values of MCYs was detected, except for the maximum value of $24.1954 \mu \mathrm{g} . \mathrm{L}^{-1}$ in Garagalheiras in 2009, followed by 2009 and 2011 . The minimum value was found in Itans (March 2010) corresponding to $0.00227 \mu \mathrm{g} . \mathrm{L}^{-1}$. During the study, the mean values of MCYs in the rainy season were higher than in the dry season (Table 3) and these differences were statistically significant for the period of 2009-2011 $(\mathrm{F}=44.073 ; p<0.05)$ (Figure 6$)$ and in each year (2009: $\mathrm{F}=16.225 ; p<0.05 ; 2010: \mathrm{F}=46.643 ; p<0.05$ and 2011: $\mathrm{F}=7.989 ; p<0.05$ ).

Regarding saxitoxins concentrations, the year that showed the highest values was 2010, followed by 2009 and 2011 . The maximum value found

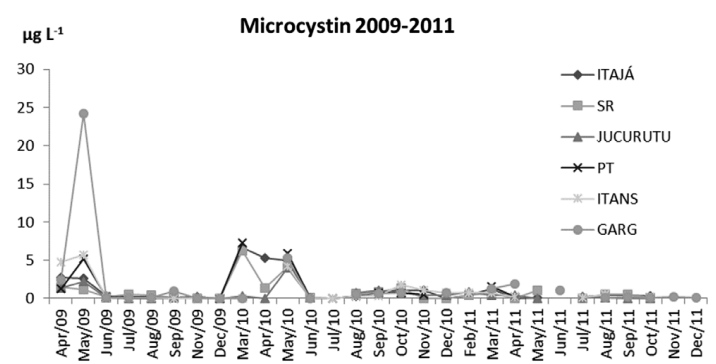

Figure 4. Microcystins values $\left(\mu \mathrm{g} \mathrm{L}^{-1}\right)$ found in the sampling points between 2009 and 2011. SR: São Rafael; PT: Passagem das Traíras and GARG: Gargalheiras.

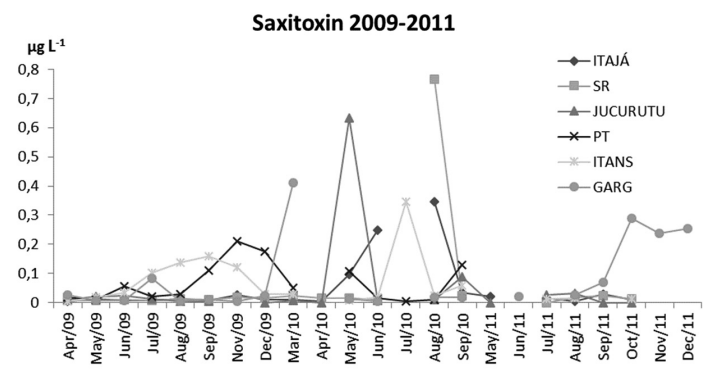

Figure 5. Saxitoxins values $\left(\mu \mathrm{g} \mathrm{L}^{-1}\right)$ found in the sample points between 2009 and 2011. SR: São Rafael; PT: Passagem das Traíras and GARG: Gargalheiras.

was $0.766 \mu \mathrm{g} \cdot \mathrm{L}^{-1}$ in São Rafael in August 2010 and the minimum was $0.003 \mu . \mathrm{L}^{-1}$ in Jucurutu in August 2009.

In this study, the comparisons showed no statistical difference in the levels of saxitoxins between dry and rainy season in the period of 2009-2010 ( $p>0.05)$. Also, the analyses of each year independently showed no difference in 2010 (Table 3). However, in 2009 the levels of saxitoxins were higher in the dry period compared to the rainy season $(\mathrm{F}=14.771 ; p<0.05)$.

\subsection{Composition and density of cyanobacteria}

All samples were analyzed under the microscope and revealed the presence of cyanobacteria. It was possible to identify 21 species of cyanobacteria, 11 of them considered potentially producers of cyanotoxins, according Chorus \& Bartram (1999). The average relative density of cyanobacteria to total phytoplankton was above $89 \%$ in all samples.

In relation to the density of cyanobacteria (Figure 7), the year that showed the highest values of each setting was 2009, except for the highest value in PT corresponding to $23.5 \times 10^{5} \mathrm{cel}^{\mathrm{m}} \mathrm{ml}^{-1}$ in December 2010. The minimum value was 
Table 3. Concentrations of microcystins and saxitoxins (Mean \pm standard deviation) in reservoirs studied between 2009 and 2011.

\begin{tabular}{|c|c|c|c|c|c|c|}
\hline MICROCYSTIN $\left(\mu \mathrm{g} \mathrm{L}^{-1}\right)$ & ITAJÁ & SR & JUCURUTU & PT & ITANS & GARG \\
\hline Rainy period 2009-2011 & $2.97( \pm 2.5)$ & $1.98( \pm 1.7)$ & $1.52( \pm 0.8)$ & $3.58( \pm 2.9)$ & $2.62( \pm 2.3)$ & $5.84( \pm 6.5)$ \\
\hline Dry period 2009-2011 & $0.44( \pm 0.4)$ & $0.42( \pm 0.3)$ & $0.24( \pm 0.3)$ & - & $0.36( \pm 0.3)$ & $0.38( \pm 0.3)$ \\
\hline Rainy season 2009 & $2.73( \pm 0.1)$ & $1.31( \pm 0.2)$ & $1.84( \pm 0.6)$ & $3.24( \pm 2.8)$ & $5.19( \pm 0.7)$ & $13.29( \pm 15.4)$ \\
\hline Rainy Period 2010 & $5.62( \pm 0.9)$ & $3.90( \pm 2.4)$ & $2.15( \pm 2.7)$ & $6.64( \pm 1.0)$ & $2.09( \pm 3.0)$ & $2.64( \pm 3.7)$ \\
\hline Rainy Period 2011 & $0.57( \pm 0.6)$ & $0.74( \pm 0.3)$ & $0.57( \pm 0.3)$ & $0.86( \pm 1.0)$ & $0.59( \pm 0.3)$ & $1.60( \pm 0.5)$ \\
\hline Dry period 2009 & $0.15( \pm 0.1)$ & $0.21( \pm 0.2)$ & $0.08( \pm 0.1)$ & $0.06( \pm 0.1)$ & $0.08( \pm 0.0)$ & $0.20( \pm 0.4)$ \\
\hline Dry Period 2010 & $0.85( \pm 0.4)$ & $0.70( \pm 0.5)$ & $0.55( \pm 0.3)$ & $0.47( \pm 0.3)$ & $0.72( \pm 0.6)$ & $0.67( \pm 0.1)$ \\
\hline Dry Period 2011 & $0.33( \pm 0.1)$ & $0.35( \pm 0.2)$ & $0.09( \pm 0.0)$ & - & $0.27( \pm 0.2)$ & $0.28( \pm 0.4)$ \\
\hline \multicolumn{7}{|l|}{ SAXITOXIN $\left(\mu \mathrm{g} \mathrm{L}^{-1}\right)$} \\
\hline Rainy period 2009-2010 & $0.02( \pm 0.0)$ & $0.01( \pm 0.0)$ & $0.17( \pm 0.2)$ & $0.05( \pm 0.0)$ & $0.01( \pm 0.0)$ & $0.11( \pm 0.1)$ \\
\hline Dry period 2009-2010 & $0.11( \pm 0.1)$ & $0.14( \pm 0.2)$ & $0.02( \pm 0.0)$ & $0.07( \pm 0.0)$ & $0.11( \pm 0.0)$ & $0.02( \pm 0.0)$ \\
\hline Rainy period 2009 & $0.01( \pm 0.0)$ & $0.01( \pm 0.0)$ & $0.01( \pm 0.0)$ & $0.01( \pm 0.0)$ & $0.01( \pm 0.0)$ & $0.02( \pm 0.0)$ \\
\hline Rainy period 2010 & $0.04( \pm 0.1)$ & $0.02( \pm 0.0)$ & $0.32( \pm 0.4)$ & $0.08( \pm 0.0)$ & $0.02( \pm 0.0)$ & $0.21( \pm 0.3)$ \\
\hline Dry period 2009 & $0.01( \pm 0.0)$ & $0.01( \pm 0.0)$ & $0.01( \pm 0.0)$ & $0.11( \pm 0.1)$ & $0.11( \pm 0.1)$ & $0.02( \pm 0.0)$ \\
\hline Dry period 2010 & $0.21( \pm 0.2)$ & $0.27( \pm 0.4)$ & $0.04( \pm 0.0)$ & $0.04( \pm 0.1)$ & $0.11( \pm 0.2)$ & $0.01( \pm 0.0)$ \\
\hline Dry period 2011 & $0.01( \pm 0.0)$ & $0.02( \pm 0.0)$ & $0.03( \pm 0.0)$ & - & $0.01( \pm 0.0)$ & $0.15( \pm 0.1)$ \\
\hline
\end{tabular}

SR: São Rafael; PT: Passagem das Traíras and GARG: Garagalheiras.

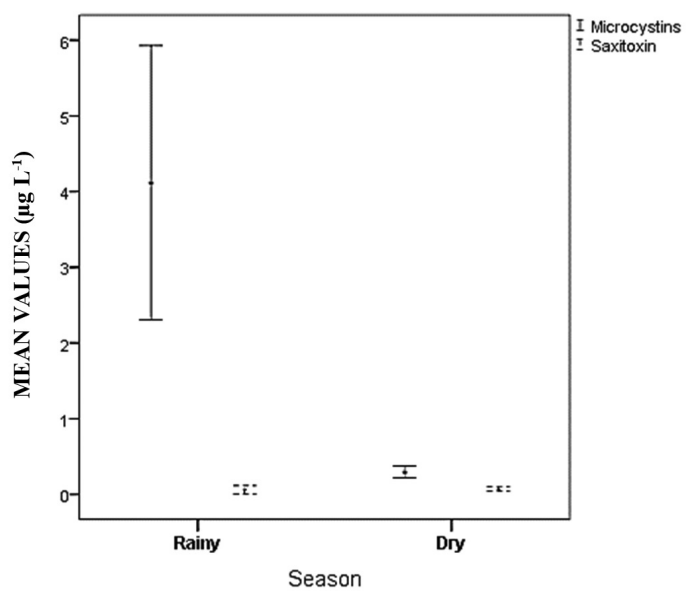

Figure 6. Mean values of cyanotoxins during dry and rainy seasons.

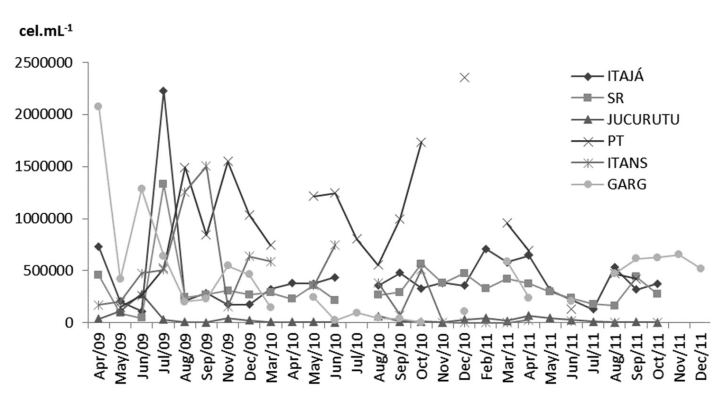

Figure 7. Densities of cyanobacteria $\left(\right.$ cel. $\mathrm{ml}^{-1}$ ) in the sample points between 2009 and 2011. SR: São Rafael; PT: Passagem das Traíras and GARG: Gargalheiras.
424 cel. $\mathrm{ml}^{-1}$ in Itans in 2011 . The average density for the three years of the sampling points was $4.16 \times 10^{5} \mathrm{cel} . \mathrm{ml}^{-1}$.

In all years, there were dominant microcystin producing species (Table 4) (Microcystis aeruginosa, Anabaena circinalis and Planktothrix agardhii) and dominant saxitoxins producing species (Cylindrospermopsis raciborskii, Planktothrix agardhii, Aphanizomenon gracile and Anabaena circinalis). Among them, the most frequent in all sampling points during the three years of study were Planktothrix agardhii, Microcystis spp and Cylindrospermopsis raciborskii. Microcystis spp, was represented by $M$. aeruginosa, $M$. panniformis and M. Protocystis .

\section{Discussion}

In Brazil and in the five continents of the world, the presence of microcystins and saxitoxins in water for human consumption has been reported over the years to the present day. In Brazil, the presence of MCYs in the northeast region has been reported by Piccin-Santos \& Bittencourt-Oliveira (2012) (by ELISA or HPLC with levels between 0.16 and $8.8 \mu \mathrm{g} . \mathrm{L}^{-1}$ ); Chelappa et al. (2008) (HPLC with levels between 0.07 to $\left.8.73 \mu \mathrm{g} . \mathrm{L}^{-1}\right)$ and Costa et al. (2006b) (by HPLC with levels between 0.16 and $\left.8.8 \mu \mathrm{g} . \mathrm{L}^{-1}\right)$. In the northern region it has been reported by Sá et al. (2010) (by HPLC with levels 
Table 4. Potentially toxic species of cyanobacteria that were dominant in the studied sample points between 2009 and 2011.

\begin{tabular}{|c|c|c|c|c|c|c|c|c|c|c|c|c|}
\hline \multirow{2}{*}{$\begin{array}{c}\text { Year } 2009 \\
\text { Cyanobacterias }\end{array}$} & \multicolumn{2}{|c|}{ ITAJÁ } & \multicolumn{2}{|c|}{ SR } & \multicolumn{2}{|c|}{ JUCURUTU } & \multicolumn{2}{|c|}{ ITANS } & \multicolumn{2}{|c|}{ PT } & \multicolumn{2}{|c|}{ GARG } \\
\hline & RAIN & DRY & RAIN & DRY & RAIN & DRY & RAIN & DRY & RAIN & DRY & RAIN & DRY \\
\hline Planktothrix agardhii & $\mathrm{x}$ & & $x$ & & & $\mathrm{x}$ & & & $\mathrm{x}$ & $x$ & & \\
\hline Microcystis spp ${ }^{* *}$ & $x$ & $x$ & & $x$ & & & $x$ & $x$ & & & $x$ & $x$ \\
\hline Cilindrospermopsis raciborskii & & $x$ & & $x$ & & & & $x$ & $x$ & $x$ & $x$ & \\
\hline Anabaena spp* & & & & & & & $x$ & & & & $x$ & \\
\hline \multirow{2}{*}{ Year 2010} & \multicolumn{2}{|c|}{ ITAJÁ } & \multicolumn{2}{|c|}{ SR } & \multicolumn{2}{|c|}{ JUCURUTU } & \multicolumn{2}{|c|}{ ITANS } & \multicolumn{2}{|c|}{ PT } & \multicolumn{2}{|c|}{ GARG } \\
\hline & RAIN & DRY & RAIN & DRY & RAIN & DRY & RAIN & DRY & RAIN & DRY & RAIN & DRY \\
\hline Planktothrix agardhii & $x$ & $x$ & & $x$ & & & & & $x$ & & & \\
\hline Microcystis spp ${ }^{* \star}$ & & & $x$ & & & & & & & $x$ & $x$ & $x$ \\
\hline Cilindrospermopsis raciborskii & $x$ & $x$ & $x$ & $x$ & & & $\mathrm{x}$ & $x$ & $x$ & $x$ & $x$ & $x$ \\
\hline Aphanizomenon gracile & $x$ & & & & & $x$ & & & & & $x$ & \\
\hline Anabaena spp* & & & & & & & & & & & & $\mathrm{x}$ \\
\hline \multirow{2}{*}{ Year 2011} & \multicolumn{2}{|c|}{ ITAJÁ } & \multicolumn{2}{|c|}{ SR } & \multicolumn{2}{|c|}{ JUCURUTU } & \multicolumn{2}{|c|}{ ITANS } & \multicolumn{2}{|c|}{ PT } & \multicolumn{2}{|c|}{ GARG } \\
\hline & RAIN & DRY & RAIN & DRY & RAIN & DRY & RAIN & DRY & RAIN & DRY & RAIN & DRY \\
\hline Planktothrix agardhii & $x$ & $x$ & $x$ & $x$ & $x$ & & $x$ & & & $x$ & & $x$ \\
\hline Microcystis spp ${ }^{* \star}$ & & & & & & & & $x$ & & & $x$ & \\
\hline Cilindrospermopsis raciborskii & $x$ & $x$ & $x$ & $x$ & & & $x$ & & $x$ & $x$ & $x$ & $x$ \\
\hline Anabaena circinalis & & & & & & & & & & & $x$ & \\
\hline
\end{tabular}

RAIN $=$ rainy season and DRY $=$ dry period. Anabaena $\mathrm{spp}^{*}=A$. circinalis and $A$. planctonica and Microcystis spp $^{* *}=$ M. aeruginosa, $M$. Panniformis and M.protocystis. SR: São Rafael; PT: Passagem das Traíras and GARG: Garagalheiras.

between 0.23 and $\left.0.55 \mathrm{mg} . \mathrm{L}^{-1}\right)$. In the Midwest region the occurrence of MCYs was reported by Oliveira et al. (2013) (not quantified by HPLC). In the Southeast, they were reported by FerrãoFilho et al. (2009) (HPLC between 1.2 and $4.5 \mu \mathrm{g} \mathrm{L}^{-1}$ ); Sotero-Santos et al. (2008) (by ELISA between 28 and $45 \mu \mathrm{g} . \mathrm{L}^{-1}$ ) and Hilborn et al. (2013). In the southern region, MCYs have been detected by HPLC with levels between 0.161 and $1.145 \mu \mathrm{g} \cdot \mathrm{mg}^{-1}$ (Matthiensen et al. 1999).

The presence of saxitoxins was reported in sources for human water supply in the northeast region of Brazil (Costa et al., 2006b; Molica et al., 2005), Southeast (Ferrão-Filho et al., 2009; Anjos et al., 2006) and in the southern region (Yunes et al., 2003).

The occurrence of microcystins have also been reported in several countries as in Europe: in Spain in reservoirs with levels between 0.055 and $1.032 \mu \mathrm{g} \mathrm{g}^{-1}$ (Asencio, 2013) and PawlikSkowrońska et al. (2013) described maximum value of microcystin corresponding to $22.2 \mu \mathrm{g} \mathrm{L}^{-1}$ in a reservoir situated in Lublin (Poland) and, Bláha et al. (2010) described levels of MCYs in water of $36.9 \mu \mathrm{gL}^{-1}$ in the Czech Republic. In South America, in Rio de La Plata - Uruguay, Pírez et al. (2013) detected $65 \mu \mathrm{g} \mathrm{L} \mathrm{L}^{-1}$. In Central America, Romero-Oliva et al. (2014) described values of MCYs (intra- and extracellular 1931 and $90 \mathrm{mg}$ $\mathrm{L}^{-1}$, respectively) in Lake Amatitlán (Guatemala).
In North America, in the San Francisco Estuary, USA (Lehman et al., 2013), between $0.79 \mathrm{ng} \mathrm{L}^{-1}$ and $29 \mathrm{ng} \mathrm{L}^{-1}$.

In Africa, in the Nile River - Egypt, microcystins were reported between 1.6 and $4.1 \mathrm{mg} \mathrm{g}^{-1}$ in water for public supply (Mohamed et al., 2006). In Oceania, in the Murray River (Australia) levels between 0.028 and $0.036 \mathrm{mg} \mathrm{L}^{-1}$ were also reported in reservoirs for public use (Bowling et al., 2013). In Asia, in Saudi Arabia, Mohamed (2008) described values of MCYs in the water corresponding to $5.7 \mu \mathrm{g} \mathrm{L}^{-1}$ and both microcystins and saxitoxins were also reported in lakes and reservoirs in Greece (3.9 to $108 \mathrm{mg} \mathrm{L}^{-1}$ of MCs and 0.4 to $1.2 \mathrm{mg}$ $\mathrm{L}^{-1}$ of STXs) (Spyros \& Nikos, 2014). In France, Ledreux et al. (2010) described maximum levels of saxitoxin of $6.7 \mu \mathrm{g} \mathrm{L}^{-1}$ and maximum levels of MCYs of $89 \mu \mathrm{g} \mathrm{L}-1$.

The increasing eutrophication and dominance of cyanobacteria in the Brazilian semi-arid region is reported in the public water supply reservoirs in Pernambuco (Bouvy et al., 1999, Huszar et al., 2000); Paraíba (Vasconcelos et al., 2011) and in Rio Grande do Norte (Costa et al., 2006b; 2009; Eskinazi-Sant'ana et al., 2006; Panosso et al., 2007; Silva et al., 2011; Sousa et al., 2008). Reservoirs located in semi-arid region of Rio Grande do Norte, show annual averages of total phosphorus and chlorophyll a (Costa et al., 2009), above the limit established by The Brazilian National Environment 
Council (CONAMA) (Resolution 357/05) of $30 \mu \mathrm{g} . \mathrm{L}^{-1}$ of total phosphorus for Class II lentic environments (reservoirs) - (Brazilian classification of water bodies for human supply established by CONAMA) (Brasil, 2005). The eutrophic condition in semiarid regions is established by values above 50-60 $\mu \mathrm{g} . \mathrm{L}^{-1}$ of total phosphorus average and above $12-15 \mu \mathrm{g} . \mathrm{L}^{-1}$ of chlorophyll $a$ average (Thornton \& Rast, 1993).

This permanent eutrophic condition, in semiarid region of Brazil, and the frequent events of intense blooms of potentially toxic cyanobacteria are associated with multiple uses of the river basin, low water transparency, warm waters, long daily sun exposure, long residence time and good availability of phosphorus and nitrogen (Costa et al., 2006b, 2009, Vasconcelos et al., 2011, Sousa et al., 2008; Silva et al., 2011).

In this study, between the years 2009 to 2011 , we emphasized the continuity of permanent dominance and abundance of potentially toxic cyanobacteria, featuring events of toxic blooms, confirmed by the presence of microcystins and saxitoxins, at six investigated points in four reservoirs. The presence of MCYs with concentrations above $1 \mu \mathrm{g}$. $\mathrm{L}^{-1}$ - limit allowed for human consumption according to of the Brazilian Ministry of Health (Ordinance 2914/2011) (Brasil, 2011) - was detected in 27\% of samples. Moreover, despite the presence of saxitoxins $(100 \%)$, the four investigated reservoirs showed values below the indicated value for drinking water $\left(3 \mu \mathrm{g} . \mathrm{L}^{-1}\right)$, as was also reported at the Armando Ribeiro Gonçalves reservoir (Costa et al., 2006b).

Vasconcelos et al. (2011) reported the presence of microcystins above $1 \mu \mathrm{g} . \mathrm{L}^{-1}$ in $55 \%$ in the reservoirs in Paraiba (Brazil) during the dry season and 20\% during the rainy season, $15 \%$ of them presented concentrations below $1 \mu \mathrm{g} . \mathrm{L}^{-1}$. Microcystin levels, by ELISA method, were also found at levels above 1 $\mu \mathrm{g} . \mathrm{L}^{-1}$ by Spyros \& Nikos (2014) (between 3.9 and $\left.108 \mu \mathrm{g} . \mathrm{L}^{-1}\right)$, by Pírez et al. (2013) $\left(65 \mu \mathrm{g} . \mathrm{L}^{-1}\right)$ and by Sotero-Santos et al. 2008 (between 28 and 45 $\left.\mu \mathrm{g} . \mathrm{L}^{-1}\right)$ and all samples along with the co-occurrence of microcystins and saxitoxins Spyros \& Nikos (2014) and Costa et al. (2006b).

The raise of the growth rate of cyanobacteria can be influenced by certain climatic conditions such as temperature increases, surface light and raise of nutrients due to greater precipitation (Paerl \& Paul, 2012). Due to larger amount of cyanobacteria, the competition may be greater between species, which can promote the appearance of toxic strains and influence the increase in production of cianotoxins by toxic strains. Considering the influence of the environmental variables in the microcystin distribution, the temperature may represent a significant factor that may influence the production of cyanotoxins. Mohamed (2008) found values of MCYs, in the water above the limit established by WHO (World Health Organization) (1 $\left.\mu \mathrm{g} \mathrm{L}^{-1}\right)$ (Chorus \& Bartram, 1999) in temperatures ranging from $48^{\circ}$ until $70^{\circ} \mathrm{C}$. Regarding the physico-chemical variable, in the present study we identified a positive correlation only between temperature and microcystin levels, but no statistical difference between the other variables and both saxitoxin and microcystin. Similar results were described by Mohamed (2008) who found a positive correlation within intracellular microcystin content and temperature. However, Asencio (2013) did not find a correlation neither between environmental parameters (including water temperature, dissolved oxygen, conductivity and $\mathrm{pH}$ ) with values of microcystin nor between values of elevated nutrients (phosphorus and nitrogen) with values of microcystin.

However, the synergistic effect of this variables and levels of cyanotoxins were not analyzed and according to Paerl \& Paul (2012), there is a probable synergistic effect between global warming and eutrophication promoting the increase of toxinproducing cyanobacteria and in agreement, Ekvall at al. (2013) described, through an experiment, that both temperature and water color (humic content and nutrient) increase the production of mycrocystin, but when both water color and temperature were acting alone, there was no increase of microcystin. Davis et al. (2009) demonstrate that high temperature along with elevated levels of phosphorus (P) frequently influence in the production rate of toxic strains instead of non-toxic microcystis strains.

Another component which can influence the microcystin production rate is light intensities. Generally, low levels of cyanotoxins usually are found in low light intensities, and high light intensities seems to influence the transcription of genes associated with synthesis of MCYs (Kaebernick \& Neilan, 2001; Kaebernick et al., 2000). Zilliges et al. (2011) described a function of MCYs as intracellular protein-binding peptides that act in the protection against high UVR levels, which can cause a negative effect of oxidative stress.

In our study, the highest values of microcystin occurred in the rainy season of 2010 . However, 
Lehman et al. (2013) described as higher both values of microcystis and MCYs in the dry years instead of wet years. These authors defined that the concentration of MCYs raised when the abundance of microcystis increased in dry years. They also identified a seasonal threshold which was responsible for the presence of microcystis only when the temperature was higher than $19^{\circ} \mathrm{C}$. In Cordoba (Argentina), Ruiz et al. (2013) found MCYs in $97 \%$ of 35 samples collected between 1998 and 2001, with levels ranging from not detectable to $119 \mu \mathrm{g} \mathrm{L}^{-1}$. These authors also found seasonal differences in the distribution pattern of MCYs, with the highest values occurring in the summer and spring, when temperatures were higher. In spite of that, no statistical differences were detected. However, Asencio et al. (2013) did not find a significant difference between seasons for microcystin production.

The occurrence of higher MCYs levels in the rainy season (Feb-May) of 2010, corresponded to the periods of lower volume of water in reservoirs and in the rainy season of 2011 occurred the lowest levels of microcystin, corresponding to the longest and abundant period of rain during this study. The decrease of microcystin levels could have occurred because of the dilution caused by the abundant precipitation. However, another hypothesis to the decrease of MCYs (intracellular and extracellular) may have occurred because MCYs in the water column may have accumulated in the sediment due to senescence and possible subsequent sedimentation of intact cells (Wörmer et al., 2011). Although these cells are able to survive for long periods, they may suffer lysis or grazing, thus releasing the cyanotoxins in the water column (Boström et al., 1989). The sedimentation of toxic cells may represent a higher risk for water consumption without treatment or with inadequate treatment, because the removal of water occurs at the bottom of the supply reservoir, which can lead to resuspension of these cells and releasing of cyanotoxins. Besides this, when the blooms occur, toxic strains can replace non-toxic strains and vice-versa (Rinta-Kanto et al., 2009). Davis et al. (2009) described an elevated variability of toxic-strains in populations of Planktotrix and Microcystis ranging from 0.01 until $100 \%$ and this can also influence the decrease of levels of MCYs, causing low levels of toxic-strains in both population of Planktotrix and Microcystis (Krienitz et al., 2013).

According to the Brazilian Ministry of Health (ordinance 2914/2011) (Brasil, 2011), the levels of saxitoxins were low (below $3 \mu \mathrm{g} . \mathrm{l}^{-1}$ ) and other studies have also revealed low levels detected by ELISA between 0.028 and $0.036 \mu \mathrm{g} . \mathrm{L}^{-1}$ (Bowling et al., 2013) and between $0.4 \mu \mathrm{g} . \mathrm{L}^{-1}$ and $1.2 \mu \mathrm{g} . \mathrm{L}^{-1}$ (Spyros \& Nikos, 2014).

The Brazilian National Environment Council (CONAMA) (357/05 - Class II waters: reservoirs) (Brasil, 2005), set the maximum values for cyanobacteria density in waters: $50,000 \mathrm{cel} . \mathrm{mL}^{-1}$. Regarding the density of cyanobacteria, $76 \%$ of the values were above the limit. By analyzing the average of three years for each environment, only Jucurutu showed a mean value within the allowed $\left(0.34 \times 10^{5} \mathrm{cel} . \mathrm{mL}^{-1}\right)$. The lower density of cyanobacteria at this point can be explained by the characteristic of a lotic environment, which is distinguished from other sampling points that are lentic environments. The low residence time favours the dispersion and discriminate the permanence of cyanobacteria.

The high contribution of cyanobacteria to total phytoplankton density (>89\%) was also reported by Ferrão-Filho et al. (2009), Dantas et al. (2011), Costa et al. (2006b, 2009) and Chellapa et al. (2008). The complexity of the emergence and establishment of these cyanobacteria is not yet fully understood. This phenomenon is influenced by several factors and one of the conditions favoring the blooms are high temperatures, as has been reported in several places, including Brazil (Ferrão-Filho et al., 2009), Uruguay (Pírez et al., 2013), Greece (Spyros \& Nikos, 2014), Italy (Messineo et al., 2009) and Egypt (Mohamed \& Carmichael, 2000).

Such high levels of cyanobacteria density indicate the continuity of the eutrophic state and represents an important parameter for evaluating the quality of water for human consumption. High density values of cyanobacteria were also found by Messineo et al. (2009), ranging between $10^{6}$ and $200 \times 10^{9} \mathrm{cel} . \mathrm{ml}^{-1}$, and other studies in the the Brazilian semi-arid region by Molica et al. (2002, 2005), Bouvy et al. (1999, 2003) and Vasconcelos et al. (2011).

In four reservoirs, we identified five genera of potentially toxin-producing cyanobacteria, including four microcystin toxin-producing with high values of microcystin corresponding to $24.19 \mu \mathrm{g} . \mathrm{L}^{-1}$. Asencio (2013) described in seven reservoirs 10 toxin-producing genera including seven microcystin toxin-producing and the highest value of microcystin was $1.032 \mu \mathrm{g} \cdot \mathrm{g}^{-1}$, which was above the limit established. Krienitz et al. (2013) described both Microcystis and Planktothrix as potential microcystin producers in Lake Naivasha 
(Kenya). He also found values of MCYs in all samples analyzed (2008 to 2013) in the range of $0.001-0.041 \mu \mathrm{g} \mathrm{L}^{-1}$.

Mohamed (2008) found a positive correlation $(\mathrm{r}=0.45-0.93)$ between values of intracellular microcystin with biovolume and abundance of many species (at least seven), yet only two of them, Oscillatoria limosa and Synechococcus lividus, were able to produce MCYs. Besides that, Oscillatoria limosa was present only in one of three studied sites.

The maximum density values did not correspond to the maxima found cyanotoxins. Other studies have also found no relationship between the density of cyanobacteria and cyanotoxins values (Messineo et al., 2009; Pírez et al., 2013) neither have found a linear relationship between cell density and MCYs, demonstrating that only $30 \%$ of the microcystin level variations could be explained by the density of cyanobacteria. Furthermore, they demonstrated that only $18 \%$ of microcystin levels have been explained by chlorophyll. Mohamed \& Carmichael (2000) found no correlation between the chlorophyll- $a$ content and microcystin concentration. This may be due to the fact that MCYs are tending to remain chemically stable for long periods in the environment (Chorus \& Bartram, 1999). In addition, high levels of MCYs are most common during or after a large amount of cell lysis (Pírez et al., 2013; Messineo et al., 2009). Another study found that the highest MCYs concentrations were found when there was a predominance of $M$. aeruginosa bloom (potentially microcystin-producing), even a low density of cyanobacteria (Spyros \& Nikos, 2014). This can also occur due to the possibility of non-producing, producing and potentially producing strains coexistence in the same population (BittencourtOliveira et al., 2010; Bittencourt-Oliveira \& Molica, 2003; Spyros \& Nikos, 2014).

Water contamination by microcystin and saxitoxins occurs in several locations worldwide, commonly affecting human sources of water supply. This emphasizes the necessity for the long-term monitoring of water quality. However, it is still observed the lack of a standard research and a detection method in monitoring programs, hindering a more robust comparative results analysis and making it impossible to determine a uniform profile. Regarding the water quality monitoring, among the different methods used, the ELISA cyanotoxins quantification method appears to be more beneficial to carry out constant monitoring, as it is considered to be cheap and simple and able to detect some of the 80 variants of microcystin, including the principal one, which is the most toxic (MC-LR) (Pírez et al., 2013) and some variants of saxitoxins among the 27 already known (Ho et al., 2012). Thus, this method is considered satisfactory to meet the requirements of the Ordinance of the Ministry of Health 2914/2011 (Brasil, 2011).

In summary, the MCYs and cell density of potentially toxic cyanobacteria levels above allowed in drinking water, found in this and other studies, represent a potential health risk to the human population since the conventional water treatment is not able to remove cyanotoxins. This is alarming because in many semiarid places the proper treatment is not performed. In many places the water is treated in a simplified manner, or is not treated, increasing the risk of intoxication by direct ingestion of contaminated water, even in small doses for long periods. Besides the risk of contamination by direct water consumption, there is still the possibility of contamination by eating fish, as microcystin can accumulate in fish muscle (Magalhães et al., 2001; Pawlik-Skowrońska et al. (2013) and the consumption of fresh vegetables irrigated with contaminated water (RomeroOliva et al., 2014). As the highest density values of cyanobacteria and cyanotoxins are not correlated, it is necessary and urgent to contemplate counting and quantification of cyanobacteria and cyanotoxins through a systematic monitoring specially in the water for drinking consumption.

\section{Acknowledgements}

The authors thank CAPES (Fundação para a Coordenação do Ensino Superior e Formação de Pós-Graduação) by the financial support, through a partnership between the PRODEMA/UFRN and $\mathrm{CNPq}$ (Conselho Nacional de Desenvolvimento Científico e Tecnológico), the resources allocated to CT-HIDRO/CT-SAÚDE (576887/2008-0) Project: Water and Health in Semi-Arid Region: Pathogenic Bacteria, Cyanobacteria and Cyanotoxins in Reservoirs Used for Public Supply in Rio Grande do Norte.

\section{Referências}

ANJOS, F.M., BITTENCOURT-OLIVEIRA, M.C., ZAJAC, M.P., HILLER, S., CHRISTIAN, B., ERLER, K., LUCKAS, B. and PINTO, E. Detection of harmful cyanobacteria and their toxins by both PCR amplification and LC-MS during a bloom event. Toxicon, 2006, 48(3), 239-245. http://dx.doi.org/10.1016/j.toxicon.2006.05.006. PMid:16879849 
ASENCIO, A.D. Determination of microcystins in reservoirs of different basins in a semi-arid area. Journal of Applied Phycology, 2013, 25(6), 1753-1762. http://dx.doi.org/10.1007/s10811-013-0025-4.

AZEVEDO, S.M.F.O., CARMICHAEL, W.W., JOCHIMSEN, E.M., RINEHART, K.L., LAU, S., SHAW, G.R. and EAGLESHAM, G.K. Human intoxication by microcystins during renal dialysis treatment in Caruaru-Brazil. Toxicology, 2002, 181182, 441-446. http://dx.doi.org/10.1016/S0300483X(02)00491-2. PMid:12505349

BITTENCOURT-OLIVEIRA, M.C., SANTOS, D.M. and MOURA, N.A. Toxic cyanobacteria in reservoirs in northeastern Brazil: detection using a molecular method. Brazilian Journal of Biology, 2010, 70(4), 1005-1010. http://dx.doi.org/10.1590/S151969842010000500012. PMid:21180905

BITTENCOURT-OLIVEIRA, M.C. and MOLICA, R. Cianobactéria invasora: aspectos moleculares e toxicológicos de Cylindrospermopsis raciborskii no Brasil. Biotecnologia Ciencia \& Desenvolvimento, 2003, 30, 82-90.

BLÁHA, L., BLÁHOVÁ, L., KOHOUTEK, J., ADAMOVSKÝ, O., BABICA, P. and MARSÁLEK, B. Temporal and spatial variability of cyanobacterial toxins microcystins in three interconnected freshwater reservoirs. Journal of the Serbian Chemical Society, 2010, 75(9), 1303-1312. http://dx.doi.org/10.2298/ JSC100113106B.

BOSTRÖM, B., PETTERSSON, A-K. and AHLGREN, I. Seasonal dynamics of a cyanobacteria-dominated microbial community in surface sediments of a shallow, eutrophic lake. Aquatic Sciences, 1989, 51(2), 153-178. http://dx.doi.org/10.1007/BF00879300.

BOUVY, M., FALCÃO, D., MARINHO, M., PAGANO, M. and MOURA, A. Occurrence of Cylindrospermopsis (Cyanobacteria) in 39 Brazilian tropical reservoirs during 1998 drought. Aquatic Microbial Ecology, 2000, 23(1), 13-27. http://dx.doi. org/10.3354/ame023013.

BOUVY, M., MOLICA, R., OLIVEIRA, S., MARINHO, M. and BEKER, B. Dynamics of a toxic cyanobacterial bloom (Cylindrospermopsis raciborskii) in a shallow reservoir in the semi-arid of northeast Brazil. Aquatic Microbial Ecology, 1999, 20(3), 285-297. http://dx.doi.org/10.3354/ ame020285.

BOUVY, M., NASCIMENTO, S.M., MOLICA, R.J.R., FERREIRA, A., HUSZAR, V. and AZEVEDO, S.M.F.O. Limnological features in Tapacurá reservoir (northeast Brazil) during a severe drought. Hydrobiologia, 2003, 493(1-3), 115-130. http:// dx.doi.org/10.1023/A:1025405817350.

BOWLING, L.C., MERRICK, C., SWANN, J., GREEN, D., SMITH, G. and NEILAN, B.A. Effects of hydrology and river management on the distribution, abundance and persistence of cyanobacterial blooms in the Murray River, Australia. Harmful Algae, 2013, 30, 27-36. http://dx.doi. org/10.1016/j.hal.2013.08.002.

BRASIL. CONSELHO NACIONAL DE MEIO AMBIENTE - CONAMA. Resolução no 357, de 17 de março de 2005. Dispóe sobre a classificação dos corpos de água e diretrizes ambientais para o seu enquadramento, bem como estabelece as condiçóes e padrôes de lançamento de efluentes, e dá outras providências. Diário Oficial da União [da] República Federativa do Brasil, Poder Executivo, Brasília, DF, 18 mar. 2005. 27 p.

BRASIL. MINISTÉRIO DA SAÚDE. Portaria $\mathrm{n}^{\circ}$ 2.914, de 12 de dezembro de 2011. Dispóe sobre os procedimentos de controle e de vigilância da qualidade da água para consumo humano e seu padrão de potabilidade. Diário Oficial da União [da] República Federativa do Brasil, Poder Executivo, Brasília, DF, 14 dez. 2011. Seção 1, p. 26.

CALIJURI, M.C., ALVES, M.A. and SANTOS, A.C.A. Cianobactérias e cianotoxinas em águas continentais. São Carlos: Rima Editora, 2006.

CARMICHAEL, W.W. Health effects of toxin-producing cyanobacteria: "The CyanoHABs". Human and Ecological Risk Assessment: International Journal, 2001, 7(5), 1393-1407.

CHELLAPPA, N.T., CHELLAPPA, S.L. and CHELLAPPA, S. Harmful Phytoplankton Blooms and Fish Mortality in a eutrophicated reservoir of Northeast Brazil. Brazilian Archives of Biology and Technology, 2008, 51(4), 833-841.

CHEN, J. and XIE, P. Microcystin accumulation in freshwater bivalves from Lake Taihu, China, and the potential risk to human consumption. Environmental Toxicology and Chemistry, 2007, 26(5), 1066-1073. http://dx.doi.org/10.1897/06-423R1.1. PMid:17521156

CHEN, J. and XIE, P. Tissue distributions and seasonal dynamics of the hepatotoxic microcystins-LR and -RR in two freshwater shrimps, Palaemon modestus and Macrobrachium nipponensis, from a large shallow, eutrophic lake of the subtropical China. Toxicon, 2005, 45(5), 615-625. http://dx.doi.org/10.1016/j. toxicon.2005.01.003. PMid:15777958

CHORUS, I. and BARTRAM, J., eds. Toxic Cyanobacteria in water: a guide to the public health consequences, monitoring and management. London: $\mathrm{E}$ and $\mathrm{FN}$ Spon, 1999.

CODD, G.A., MORRISON, L.F. and METCALF, J.S. Cyanobacterial toxins: risk management for health protection. Toxicology and Applied Pharmacology, 2005, 203(3), 264-272. http://dx.doi.org/10.1016/j. taap.2004.02.016. PMid:15737680

COLE, G. Textbook of limnology. Saint Louis: The C.V. Mosby, 1975. 
COSTA, I.A.S., SANTOS, A.P., SILVA, A.A.L. and MELO, S.G., PANOSSO, R.F. and ARAÚJO, M.F.F. Floração de algas nocivas: ameaça às águas Potiguares. Revista Fundação de Apoio a Pesquisa do Rio Grande do Norte, 2006a, 14-16.

COSTA, I.A.S., AZEVEDO, S.M.F.O., SENNA, P.A.C., BERNARDO, R.R., COSTA, S.M. and CHELLAPPA, N.T. Occurrence of toxin-producing cyanobacteria blooms in a Brazilian semiarid reservoir. Brazilian Journal of Biology, 2006b, 66(1b), 211-219. http://dx.doi.org/10.1590/S151969842006000200005.

COSTA, I.A.S., CUNHA, S.R.S, PANOSSO, R., ARAUJO, M.F.F., MELO, J.L.S. and ESKINAZISANT'ANNA, E.M. Dinâmica de cianobactérias em açudes eutróficos do semi-árido do Rio Grande do Norte. Oecologia Brasiliensis, 2009, 13(2), 382-401.

DANTAS, E.W., MOURA, A.N. and BITTENCOURTOLIVEIRA, M.C. Cyanobacterial blooms in stratified and destratified eutrophic reservoirs in semiarid region of Brazil. Anais da Academia Brasileira de Ciências, 2011, 83(4), 1327-1338. http:// dx.doi.org/10.1590/S0001-37652011000400019. PMid:22146960

DAVIS, T.W., BERRY, D.L., BOYER, G.L. and GOBLER, C.J. The effects of temperature and nutrients on the growth and dynamics of toxic and non-toxic strains of Microcystis during cyanobacteria blooms. Harmful Algae, 2009, 8(5), 715-725. http:// dx.doi.org/10.1016/j.hal.2009.02.004.

DIETRICH, D. and HOEGER, S. Guidance values for microcystins in water and cyanobacterial supplement products (blue-green algal supplements): a reasonable or misguided approach? Toxicology and Applied Pharmacology, 2005, 203(3), 273-289. http://dx.doi. org/10.1016/j.taap.2004.09.005. PMid:15737681

DITTMANN, E. and WIEGAND, C. Cyanobacterial toxins-occurrence, biosynthesis and impact on human affairs. Molecular Nutrition \& Food Research, 2006, 50(1), 7-17. http://dx.doi.org/10.1002/ mnfr.200500162. PMid:16304634

DEPARTAMENTO NACIONAL DE OBRAS CONTRA AS SECAS - DNOCS. Recursos hidricos [online]. Fortaleza: DNOCS, 2014 [viewed $15 \mathrm{Fev}$. 2014]. Available from: http://www.dnocs.gov.br/ php/canais/recursos_hidricos/

DROBAC, D., TOKODI, N., SIMEUNOVIĆ, J., BALTIĆ, V., STANIĆ, D. and SVIRČEV, Z. Human exposure to cyanotoxins and their effects on health. Arhiv za Higijenu Rada i Toksikologiju, 2013, 64(2), 119-130. http://dx.doi.org/10.2478/100041254-64-2013-2320. PMid:23819940

EKVALL, M.K., CALLE MARTIN, J., FAASSEN, E.J., GUSTAFSSON, S., LÜRLING, M. and HANSSON, L.A. Synergistic and species-specific effects of climate change and water colour on cyanobacterial toxicity and bloom formation. Freshwater Biology, 2013, 58(11), 2414-2422.

ESKINAZI-SANT'ANNA, E.M., PANOSSO, R.F., ATTAYDE, J.L., COSTA, I.A.S., SANTOS, C.M. and ARAÚJO, M.F.F. Águas potiguares: oásis ameaçados. Ciência Hoje, 2006, 39(233), 68-71.

FERRÃO-FILHO, A.S., SOARES, M.C., ROCHA, M.I.A., MAGALHÃES, V.F. and AZEVEDO, S.M.F.O. Floraçóes de Cianobactérias tóxicas no Reservatório do Funil: dinâmica sazonal e consequências para o zooplâncton. Oecologia Brasiliensis, 2009, 13(2), 346-365.

GALVÃO, J.A., OETTERER, M., BITTENCOURTOLIVEIRA, M.C., GOUVÊA-BARROS, S., HILLER, S., ERLER, K., LUCKAS, B., PINTO, E. and KUJBIDA, P. Saxitoxins accumulation by freshwater tilapia (Oreochromis niloticus) for human consumption. Toxicon, 2009, 54(6), 891-894. http://dx.doi.org/10.1016/j.toxicon.2009.06.021. PMid:19560484

GUTIÉRREZ-PRAENA, D., JOS, Á., PICHARDO, S., MORENO, I.M. and CAMEÁN, A.M. Presence and bioaccumulation of microcystins and cylindrospermopsin in food and the effectiveness of some cooking techniques at decreasing their concentrations: a review. Food and Chemical Toxicology, 2013, 53, 139-152. http://dx.doi. org/10.1016/j.fct.2012.10.062. PMid:23200893

HILBORN, E.D., SOARES, R.M., SERVAITES, J.C., DELGADO, A.G., MAGALHÃES, V.F., CARMICHAEL, W.W. and AZEVEDO, S.M. Sublethal microcystin exposure and biochemical outcomes among hemodialysis patients. PLoS ONE, 2013, 8(7), e69518. http://dx.doi.org/10.1371/ journal.pone.0069518. PMid:23894497

HO, L., SAWADE, E. and NEWCOMBE, G. Biological treatment options for cyanobacteria metabolite removal-a review. Water Research, 2012, 46(5), 1536-1548. http://dx.doi.org/10.1016/j. watres.2011.11.018. PMid:22133838

HUSZAR, V.L.M., SILVA, L.H.S., MARINHO, M., DOMINGOS, P. and SANT'ANNA, C.L. Cyanoprokaryote assemblages in eight productive tropical Brazilian waters. Hydrobiologia, 2000, 424(1-3), 67-77. http://dx.doi. org/10.1023/A:1003996710416.

JOCHIMSEN, E.M., CARMICHAEL, W.W., AN, J.S., CARDO, D.M., COOKSON, S.T., HOLMES, C.E., ANTUNES, M.B., MELO FILHO, D.A., LYRA, T.M., BARRETO, V.S., AZEVEDO, S.M. and JARVIS, W.R. Liver failure and death after exposure to microcystins at a hemodialysis center in Brazil. The New England Journal of Medicine, 1998, 338(13), 873-878. http://dx.doi.org/10.1056/ NEJM199803263381304. PMid:9516222

KAEBERNICK, M. and NEILAN, B.A. Ecological and molecular investigations of cyanotoxin production. 
FEMS Microbiology Ecology, 2001, 35(1), 1-9. http:// dx.doi.org/10.1111/j.1574-6941.2001.tb00782.x. PMid:11248384

KAEBERNICK, M., NEILAN, B.A., BÖRNER, T. and DITTMANN, E. Light and the transcriptional response of the microcystin biosynthesis gene cluster. Applied and Environmental Microbiology, 2000, 66(8), 3387-3392. http://dx.doi.org/10.1128/ AEM.66.8.3387-3392.2000. PMid:10919796

KOMÁREK, J. and ANAGNOSTIDIS, K. Cyanoprokaryota 1. Teil: Chroococcales. In H. ETTL, G. GÄRTNER, H. HEYNIG and D. MOLLENHAUER, eds. Süsswasserflora von Mitteleuropa. New York: Gustav Fischer, JenaStuttgart-Lübeck-Ulm, 1998, vol. 19, n. 1, pp. 1-548.

KOMÁREK, J. and ANAGNOSTIDIS, K. Cyanoprokaryota - 2. Teil: 2nd Part: Oscillatoriales. In B. BÜDEL, L. KRIENITZ, G. GÄRTNER and M. SCHAGERL, eds. Süsswasserflora von Mitteleuropa. Heidelberg: Elsevier, 2005, vol. 19, no. 2, pp. 1-758.

KOMÁREK, J. and ANAGNOSTIDIS, K. Modern approach to the classification system of Cyanophytes 4-Nostocales. Algological Studies, 1989, 56, 247-345. Supplement volumes.

KRIENITZ, L., DADHEECH, P.K., FASTNER, J. and KOTUT, K. The rise of potentially toxin producing cyanobacteria in Lake Naivasha, Great African Rift Valley, Kenya. Harmful Algae, 2013, 27, 42-51. http://dx.doi.org/10.1016/j.hal.2013.04.005.

LEDREUX, A., THOMAZEAU, S., CATHERINE, A., DUVAL, C., YÉPRÉMIAN, C., MARIE, A. and BERNARD, C. Evidence for saxitoxins production by the cyanobacterium Aphanizomenon gracile in a French recreational water body. Harmful Algae, 2010, 10(1), 88-97. http://dx.doi.org/10.1016/j. hal.2010.07.004.

LEHMAN, P., MARR, K., BOYER, G., ACUNA, S. and TEH, S. Long-term trends and causal factors associated with Microcystis abundance and toxicity in San Francisco Estuary and implications for climate change impacts. The International Journal of Aquatic Sciences, 2013, 718(1), 141-158.

LUND, J.W.G., KIPLING, C. and LE CREN, E.D. The invert microscope method of estimating algal numbers and the statistical basis of estimations by counting. Hydrobiologia, 1958, 11(2), 143-170. http://dx.doi.org/10.1007/BF00007865.

MAGALHÁES, V.F., SOARES, R.M. and AZEVEDO, S.M. Microcystin contamination in fish from the Jacarepaguá Lagoon (Rio de Janeiro, Brazil): ecological implication and human health risk. Toxicon, 2001, 39(7), 1077-1085. http://dx.doi.org/10.1016/ S0041-0101(00)00251-8. PMid:11223098
MATTHIENSEN, A., YUNES, J.S. and CODD, G.A. Ocorrência, distribuição e toxicidade de cianobactérias no estuário da Lagoa dos Patos, RS. Revista Brasileira de Biologia, 1999, 59(3), 361-376. http://dx.doi.org/10.1590/S003471081999000300002. PMid:10765462

MESSINEO, V.S., BOGIALLI, S., MELCHIORRE, N., SECHI, A., LUGLIÈ, P., CASIDDU, M.A., MARIANI, B.M., PADEDDA, A.D., CORCIA, R., MAZZA, E., CARLONI, E. and BRUNO, M. Cyanobacterial toxins in Italian freshwaters. Limnologica-Ecology and Management of Inland Waters, 2009, 39(2), 95-106. http://dx.doi.org/10.1016/j. limno.2008.09.001.

MOHAMED, Z.A. and CARMICHAEL, W.W. Seasonal variation in microcystin levels of river Nile water at Sohag City, Egypt. International Journal of Limnology, 2000, 36(4), 227-234. http://dx.doi. org/10.1051/limn/2000020.

MOHAMED, Z. A., EL-SHAROUNY, H. M. and ALI, W.S.M. Microcystin production in benthic mats of cyanobacteria in the Nile River and irrigation canals, Egypt. Toxicon, 2006, 47(5), 584-590.

MOHAMED, Z.A. Toxic cyanobacteria and cyanotoxins in public hot springs in Saudi Arabia. Toxicon, 2008, 51(1), 17-27. http://dx.doi.org/10.1016/j. toxicon.2007.07.007. PMid:17825867

MOLICA, R., ONODERA, H., GARCIA, C., RIVAS, M., ANDRINOLO, D., NASCIMENTO, S., MEGURO, H., OSHIMA, O., AZEVEDO, S. and LAGOS, N. Toxins in the freshwater cyanobacterium Cylindrospermopsis raciborskii (Cyanophyceae) isolated from Tabocas reservoir in Caruaru, Brazil, including demonstration of a new saxitoxin analogue. Phycologia, 2002, 41(6), 606-611. http://dx.doi. org/10.2216/i0031-8884-41-6-606.1.

MOLICA, R.J., OLIVEIRA, E.J., CARVALHO, P.V., COSTA, N.A., CUNHA, M.C., MELO, G.L. and AZEVEDO, S.M.F.O. Occurrence of saxitoxin and an anatoxin-a(s)-like anticholinesterase in a Brazilian drinking waters supply. Harmful Algae, 2005, 4(4), 743-753. http://dx.doi.org/10.1016/j. hal.2004.11.001.

OLIVEIRA, N.B., SCHWARTZ, C.A., BLOCH JUNIOR, C., PAULINO, L. and PIRES JUNIOR, O.R. Bioacumulation of cyanotoxins in Hypophthalmichthys molitrix (silver carp) in Paranoá Lake, Brasilia-DF, Brazil. Bulletin of Environmental Contamination and Toxicology, 2013, 90(3), 308-313. http://dx.doi.org/10.1007/s00128-012-0873-7. PMid:23179164

PAERL, H.W. and PAUL, V.J. Climate change: links to global expansion of harmful cyanobacteria. Water Research, 2012, 46(5), 1349-1363. http://dx.doi. org/10.1016/j.watres.2011.08.002. PMid:21893330

PANOSSO, R., COSTA, I.A.S., SOUZA, N.R., CUNHA, S.R.S., ATTAYDE, J.L. and GOMES, 
F.C.F. Cianobactérias e cianotoxinas em reservatórios do Estado do Rio Grande do Norte e o potencial controle das floraçóes pela tilápia do Nilo (Oreochromis niloticus). Oecologia Brasiliensis, 2007, 11(3), 433449.

PAPADIMITRIOU, T., KAGALOU, I., STALIKAS, C., PILIDIS, G. and LEONARDOS, I.D. Assessment of microcystin distribution and biomagnification in tissues of aquatic food web compartments from a shallow lake and evaluation of potential risks to public health. Ecotoxicology (London, England), 2012, 21(4), 1155-1166. http://dx.doi.org/10.1007/s10646-0120870-y. PMid:22383140

PAWLIK-SKOWROŃSKA, B., KALINOWSKA, R. and SKOWROŃSKI, T. Cyanotoxin diversity and food web bioaccumulation in a reservoir with decreasing phosphorus concentrations and perennial cyanobacterial blooms. Harmful Algae, 2013, 28, 118-125. http://dx.doi.org/10.1016/j. hal.2013.06.002.

PICCIN-SANTOS, V. and BITTENCOURTOLIVEIRA, M.C. Toxic cyanobacteria in four Brazilian water supply reservoirs. Journal of Environmental Protection, 2012, 3, 68-73. http:// dx.doi.org/10.4236/jep.2012.31009.

PÍREZ, M., GONZALEZ-SAPIENZA, G., SIENRA, D., FERRARI, G., LAST, M., LAST, J.A. and BRENA, B.M. Limited analytical capacity for cyanotoxins in developing countries may hide serious environmental health problems: simple and affordable methods may be the answer. Journal of Environmental Management, 2013, 114, 63-71. http://dx.doi.org/10.1016/j.jenvman.2012.10.052. PMid:23220602

RINTA-KANTO, J.M., KONOPKO, E.A., DEBRUYN, J.M., BOURBONNIERE, R.A., BOYER, G.L. and WILHELM, S.W. Lake Erie Microcystis: relationship between microcystin production, dynamics of genotypes and environmental parameters in a large lake. Harmful Algae, 2009, 8(5), 665-673. http:// dx.doi.org/10.1016/j.hal.2008.12.004.

ROMERO-OLIVA, C.S., CONTARDO-JARA, V., BLOCK, T. and PFLUGMACHER, S. Accumulation of microcystin congeners in different aquatic plants and crops-a case study from lake Amatitlán, Guatemala. Ecotoxicology and Environmental Safety, 2014, 102, 121-128. http://dx.doi.org/10.1016/j. ecoenv.2014.01.031. PMid:24530727

RUIZ, M., GALANTI, L., RUIBAL, A.L., RODRIGUEZ, M.I., WUNDERLIN, D.A. and AMÉ, M.V. First report of Microcystins and anatoxin-a Co-occurrence in San Roque Reservoir (Córdoba, Argentina). Water, Air, \& Soil Pollution, 2013, 224, 1593. http://dx.doi.org/10.1007/s11270013-1593-2.

SÁ, L.L.C.D., VIEIRA, J., MENDES, R., PINHEIRO, S.C.C., VALE, E.R., ALVES, F. and COSTA, V.
Ocorrência de uma floração de cianobactérias tóxicas na margem direita do Rio Tapajós, no Município de Santarém (Pará, Brasil). Revista Pan-Amazônica de Saúde, 2010, 1, 159-166.

SECRETARIA DO MEIO AMBIENTE E DOS RECURSOS HÍDRICOS - SEMARH. Situação volumétrica - todo o Estado [online]. Natal: SEMARH, 2010. [viewed 15 Jan. 2014]. Available from: http://www.portal.rn.gov.br/contentproducao/ aplicacao/semarh/sistema deinformacoes/ consulta/cBaciaSitVolumetrica_Detalhe. asp? CodigoEstadual $=00$

SILVA, L.A.P., ARAÚJO, F., PANOSSO, R., CAMACHO, F. and COSTA, I.A.S. As águas verdes dos Reservatórios do Rio Grande do Norte: o problema das cianobactérias e cianotoxinas. Boletim Ablimno, 2011, 2(39), 1-10.

SINCLAIR, J.L., HALL, S., BERKMAN, J.A.H., BOYER, G., BURKHOLDER, J., BURNS, J., CARMICHAEL, W., DUFOUR, A., FRAZIER, W., MORTON, S.L., O’BRIEN, E. and WALKER, S. Occurrence of cyanobacterial harmful algal blooms workgroup report. Advances in Experimental Medicine and Biology, 2008, 619, 45-103. PMid:18461765.

SKULBERG, O.M. Microalgae as a source of bioactive molecules - experience from cyanophyte research. Journal of Applied Phycology, 2000, 12(3-5), 341-348.

SMITH, V.H. and SCHINDLER, D.W. Eutrophication science: where do we go from here? Trends in Ecology \& Evolution, 2009, 24(4), 201-207. http://dx.doi. org/10.1016/j.tree.2008.11.009. PMid:19246117

SOTERO-SANTOS, R.B., CARVALHO, E.G., DELLAMANO-OLIVEIRA, M.J. and ROCHA, O. Occurrence and toxicity of an Anabaena bloom in a tropical reservoir (Southeast Brazil). Harmful Algae, 2008, 7(5), 590-598. http://dx.doi.org/10.1016/j. hal.2007.12.017.

SOUSA, W., ATTAYDE, J.L., ROCHA, E.D.S. and ESKINAZI-SANT'ANNA, E.M. The response of zooplankton assemblages to variations in the water quality of four man-made lakes in semi-arid northeastern Brazil. Journal of Plankton Research, 2008, 30(6), 699-708. http://dx.doi.org/10.1093/ plankt/fbn032.

SPYROS, G. and NIKOS, Z. Cyanotoxin occurrence and potentially toxin producing cyanobacteria in freshwaters of Greece: a multi-disciplinary approach. Toxicon, 2014, 78, 1-9. http://dx.doi. org/10.1016/j.toxicon.2013.11.010;

THORNTON, J.A. and RAST, W. A test of hypotheses relating to the comparative limnology and assessment of eutrophication in semi-arid man-made lakes. In M. STRASKRABA, ed. Comparative reservoir limnology and water quality management. Netherlands: Springer, 1993, pp. 1-24. 
UHELINGER, V. Étude statisque des méthodes de dénobrement planctonique. Archives des Sciences, 1964, 17, 121-123.

UTERMÖHL, H. Zur vervollkommnung der quantitativen phytoplankton methodik. Mitteilungen. Internationale Vereiningung fuer Theoretische und Angewandte Limnologie, 1958, 9, $1-38$.

VAN APELDOORN, M.E., VAN EGMOND, H.P., SPEIJERS, G.J. and BAKKER, G.J. Toxins of cyanobacteria. Molecular Nutrition \& Food Research, 2007, 51(1), 7-60. http://dx.doi.org/10.1002/ mnfr.200600185. PMid:17195276

VASCONCELOS, J.F., BARBOSA, J.E.L., DINIZ, C.R. and CEBALLOS, B.S.O. Cianobactérias em reservatórios do Estado da Paraíba: ocorrência, toxicidade e fatores reguladores. Boletim da Sociedade Brasileira de Limnologia, 2011, 39(2), 1-20.

WÖRMER, L., CIRÉS, S. and QUESADA, A. Importance of natural sedimentation in the fate of microcystins. Chemosphere, 2011, 82(8), 1141-1146. http://dx.doi.org/10.1016/j. chemosphere.2010.11.024. PMid:21122889

YUNES, J.S., CUNHA, N.T., BARROS, L.P., PROENÇA, L.A.O. and MONSERRAT, J.M. Cyanobacterial Neurotoxins from Southern Brazil. Comments on Toxicology, 2003, 9(2), 103-115. http:// dx.doi.org/10.1080/08865140302426.

ZILLIGES, Y., KEHR, J.C., MEISSNER, S., ISHIDA, K., MIKKAT, S., HAGEMANN, M., KAPLAN, A., BÖRNER, T. and DITTMANN, E. The cyanobacterial hepatotoxin microcystin binds to proteins and increases the fitness of microcystis under oxidative stress conditions. PLoS ONE, 2011, 6(3), e17615. http://dx.doi.org/10.1371/journal. pone.0017615. PMid:21445264

Received: 21 February 2014 Accepted: 10 February 2015 